\title{
Morphometry Analysis of Stingless Bee Tetragonula iridipennis Smith (1854)
}

\author{
M. Kishan Tej ${ }^{1}{ }^{*}$, M.R. Srinivasan ${ }^{1}$, K. Vijayakumar ${ }^{2}$, \\ N. Natarajan ${ }^{1}$ and S. Mohan Kumar ${ }^{1}$ \\ ${ }^{1}$ Tamil Nadu Agricultural University Coimbatore, Tamil Nadu, India \\ ${ }^{2}$ Kongu Nadu Arts and Science College, Coimbatore, Tamil Nadu, India \\ *Corresponding author
}

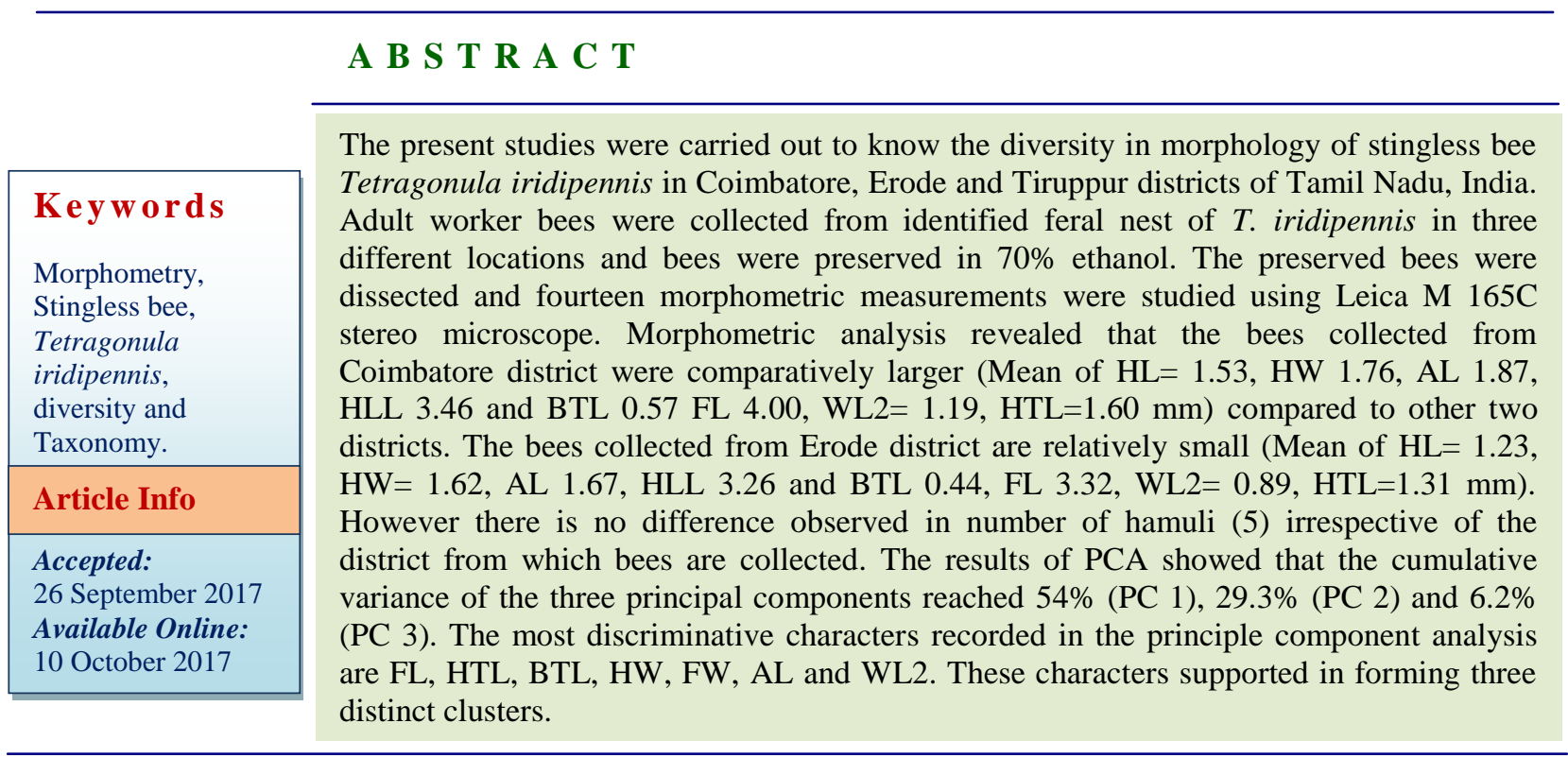

\section{Introduction}

Stingless bees belong to the family Apidae and subfamily Meliponinae. It consists of two genera Melipona and Trigona. Meliponinae includes eight genera, having 15 subgenera and more than 500 species (Wille, 1983). These bees are widely known as dammar bees in India (Rasmussen, 2013). As the name implies, these bees can't sting as their stingers are highly reduced, but they try to defend their colony from intruders using their mandibles (Michener, 2000). The stingless bees are important pollinators of various food crops and can be domesticated (Kishan et al.,
2017). Stingless bee species which were commonly seen in India are Trigona (Tetragonula) iridipennis (Raakhee and Devanesan, 2000; Swaminathan, 2000 and Danaraddi, 2007). Apart from T. iridipennis, seven other stingless bee species were also reported from India. Though stingless bees are abundant in southern part of India (Rasmussen, 2013). Earlier studies on stingless bees were conducted on biology, nesting behaviour, morphometric characters, foraging behaviour and mellisopalynology (Roopa, 2002; Batista et al., 2003; Devanesan 
et al., 2003; Franck et al., 2004; Gajanan, 2005; Roubik, 2006; Bassindale and Harrison Matthews, 2009; Nayak Pavithra et al., 2013 and Rahman and Das, 2013). However exclusive studies on species diversity of Trigona in different parts of India are lacking. Some research on distribution of $T$. iridipennis was done in southern part of India (Vijaykumar and Jeyaraj, 2014). Morphometric taxonomy is one of the most widely used classification of organisms. Some attempts were made earlier to classify stingless bees based on their body size, number of hamuli, length of fore wing, hind wing and cephalic characters etc. Apart from phylogeny, major part of the morphological variation in Meliponini occurs independently due to the fact that, for social bees, worker body size has been generally considered as an adaptation to foraging activity and floral resource exploitation.

Earlier biometric investigations especially in India were based on few morphological characters and geographic samples which lacked proper statistical analysis of data (Kapil, 1956; Narayanan et al., 1960 a, b; Kshirsagar, 1976; Venkatasubbayya, 1938; Rahman and Singh, 1948; Jaggannadham and Goyal, 1980; Kshirsagar and Ranade, 1981; Kshirsagar, 1973; Maa, 1953; Sakai, 1958; Akahira and Sakagami, 1959; Bingham, 1897). Ruttner (1988) for the first time used factorial, principal component and multivariate discriminant analysis methods to study the variation among the population of Apiscerana (Indian honey bee).

Ruttner, using morphological characters and computer assisted standard statistical methods distinguished the following four different subspecies of Apiscerana (Apiscerana cerana, Apiscerana himalaya, Apiscerana indica and Apiscerana japonica)

Hepburn et al., (2001) re-examined the earlier list of morphometric parameters used by
Ruttner (1988) and Alpatov (1929) performing a factor analysis, revealed that there are four morphoclusters of Indian honey bee. Studies on combination of morphometry and statistical analysis for Stingless bees are scarce in India and so the present study was taken.

\section{Materials and Methods}

\section{Standard morphometrics}

Adult worker bees were collected from identified feral nest of $T$. iridipennis in three different locations (Table 1) and bees were preserved in $70 \%$ ethanol. The preserved bees were dissected and fourteen morphometric measurements were studied (Table 2) by using Leica M 165C stereo microscope (Fig. 1-3). Some of the parameters are represented in numbers while lengths or widths of morphometric characters and are reported in millimeter. The morphological characters were measured for each worker bee based on previous literature (Ruttner, 1988 and Sakagami, 1978).

\section{Data analysis}

The statistical procedure was to perform a factor analysis by using 14 morphometric characters for 30 bees collected from three districts of Tamil Nadu, India. Multivariate statistical analysis, i.e., analysis of variance, factor analysis, principal components analysis and discriminant function analysis were used to detect population variation within $T$. iridipennis. The morphometric variation in female bee samples was studied using principal component analysis (PCA) based on covariance matrices. The first principal component explains the major part of the variance present in the original characters. Stepwise discriminant analysis using principal component clusters was carried out to determine the most discriminatory variables to enter into the discriminant functions. All 
statistical analyses were done by using SPSS 16.0 statistical package.

\section{Results and Discussion}

Standard morphometrics analyses were performed to find out population variation within Tetragonula iridipennis collected from three different localities representing in Coimbatore, Erode and Tiruppur districts of Tamil Nadu, India. A total of 14 morphometric characters was measured and analyzed the morphometric variations within T. iridipennis. The mean values and standard deviations of the 14 morphometric characters are shown in table 4.

\section{Cephalic region}

Head length, head width, distance between two lateralocelli, ocello - ocular distance and antennal length were the characters measured in cephalic region and found that the head length varied from 1.23 (Erode) to $1.53 \mathrm{~mm}$ (Coimbatore). Head width ranged between $1.62 \mathrm{~mm}$ in Erode samples to $1.76 \mathrm{~mm}$ in Coimbatore. Mean antennal length of the bees were in the range of $1.67 \mathrm{~mm}$ in bees collected from Erode, $1.78 \mathrm{~mm}$ in samples collected from tirupur and $1.87 \mathrm{~mm}$ from Coimbatore. However ocello - ocular distance was $0.21 \mathrm{~mm}$ in Coimbatore and Erode districts and 0.22 $\mathrm{mm}$ in Tiruppur district. Our results are in concurrence with Danaraddi (2007) who reported that the width of the head including eyes in $T$. iridipennis ranged from 1.52 to $1.61 \mathrm{~mm}$. Franck et al., (2004) reported that head length and width was $1.40 \pm 0.04 \mathrm{~mm}$ and $1.72 \pm 0.05 \mathrm{~mm}$ in T. mellipes, $1.36 \pm 0.04$ $\mathrm{mm}$ and $1.73 \pm 0.03 \mathrm{~mm}$ in T. carbonaria, $1.50 \pm 0.04 \mathrm{~mm}$ and $1.86 \pm 0.05 \mathrm{~mm}$ in $T$. hockingsi and $1.41 \pm 0.01 \mathrm{~mm}$ and $1.72 \pm$ $0.03 \mathrm{~mm}$ in $T$. davenportii.

Table.1 Sampling locations and its geographical positions

\begin{tabular}{|l|l|c|c|}
\hline S.No & \multicolumn{1}{|c|}{ Location } & Collection site & Geographical position \\
\hline $\mathbf{1}$ & Coimbatore & TNAU Botanical garden & $11.0148^{\circ} \mathrm{N}, 76.9315^{\circ} \mathrm{E}$ \\
\hline $\mathbf{2}$ & Erode & ADP Apiary & $11.1179^{\circ} \mathrm{N}, 77.7888^{\circ} \mathrm{E}$ \\
\hline $\mathbf{3}$ & Tiruppur & Jain irrigation- Mango orchard & $10.4764^{\circ} \mathrm{N}, 77.2931^{\circ} \mathrm{E}$ \\
\hline
\end{tabular}

Table.2 List of morphological characteristics of worker stingless bee studied

\begin{tabular}{|l|l|l|}
\hline S. No. & Characteristics $(\mathrm{mm})$ & Abbreviation \\
\hline I. Head & \multicolumn{2}{|l|}{} \\
\hline 1 & Head length & HL \\
\hline 2 & Head width & HW \\
\hline 3 & Distance between two lateral ocelli & DBO \\
\hline 4 & Ocello - ocular distance & OOD \\
\hline 5 & Antennal length & AL \\
\hline II. Thorax & \multicolumn{2}{l}{} \\
\hline 6 & Hind leg length & HLL \\
\hline 7 & Hind tibial length & HTL \\
\hline 8 & Hind tibial width & HTW \\
\hline 9 & Hind basitarsus length & HBL \\
\hline 10 & Hind basitarsus width & HBW \\
\hline 11 & Fore wing length & FL \\
\hline 12 & Fore wing width & FW \\
\hline 13 & Bifurication between veins M and Cu & WL2 \\
\hline 14 & Number of hamuli in Hind wing & NH \\
\hline
\end{tabular}


Table.3 Mean values of morphometric characters measured for T. iridipennis from three districts

\begin{tabular}{|c|l|l|l|}
\hline Characters/ Location & Coimbatore* & Trippur* & Erode* \\
\hline HL & $1.53 \pm 0.05$ & $1.35 \pm 0.07$ & $1.23 \pm 0.06$ \\
\hline HW & $1.76 \pm 0.03$ & $1.63 \pm 0.04$ & $1.62 \pm 0.04$ \\
\hline AL & $1.87 \pm 0.02$ & $1.78 \pm 0.04$ & $1.67 \pm 0.05$ \\
\hline DBO & $0.35 \pm 0.01$ & $0.41 \pm 0.01$ & $0.32 \pm 0.01$ \\
\hline OOD & $0.21 \pm 0.01$ & $0.22 \pm 0$ & $0.21 \pm 0.01$ \\
\hline FL & $4 \pm 0.07$ & $3.38 \pm 0.07$ & $3.32 \pm 0.07$ \\
\hline FW & $1.53 \pm 0.02$ & $1.52 \pm 0.03$ & $1.17 \pm 0.03$ \\
\hline WL2 & $1.19 \pm 0.01$ & $1.14 \pm 0.03$ & $0.89 \pm 0.01$ \\
\hline NH & $5 \pm 0.00$ & $5 \pm 0.00$ & $5 \pm 0.00$ \\
\hline HLL & $3.46 \pm 0.05$ & $3.4 \pm 0.04$ & $3.26 \pm 0.06$ \\
\hline HTL & $1.62 \pm 0.03$ & $1.34 \pm 0.03$ & $1.31 \pm 0.04$ \\
\hline HTW & $0.49 \pm 0$ & $0.43 \pm 0.01$ & $0.49 \pm 0.01$ \\
\hline BTL & $0.57 \pm 0.01$ & $0.42 \pm 0.01$ & $0.44 \pm 0.01$ \\
\hline BTW & $0.26 \pm 0.01$ & $0.21 \pm 0.01$ & $0.23 \pm 0.02$ \\
\hline
\end{tabular}

*measurments in $\mathrm{mm}$

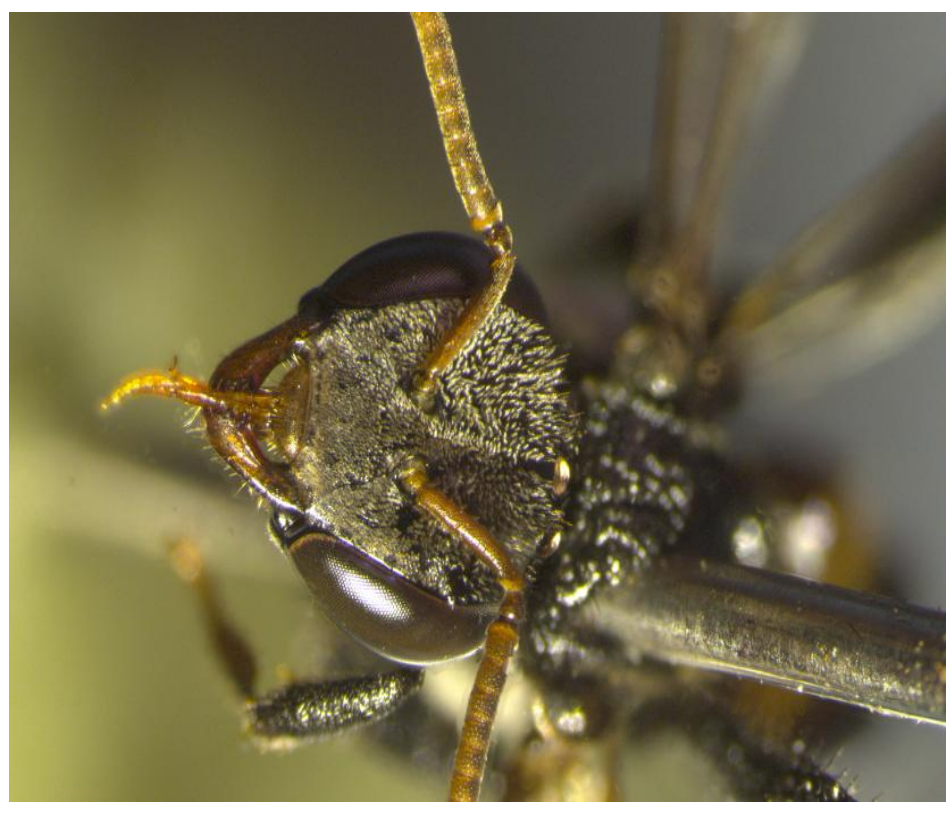

Fig.1 T. iridipennis head under Leica M 165C stereo microscope

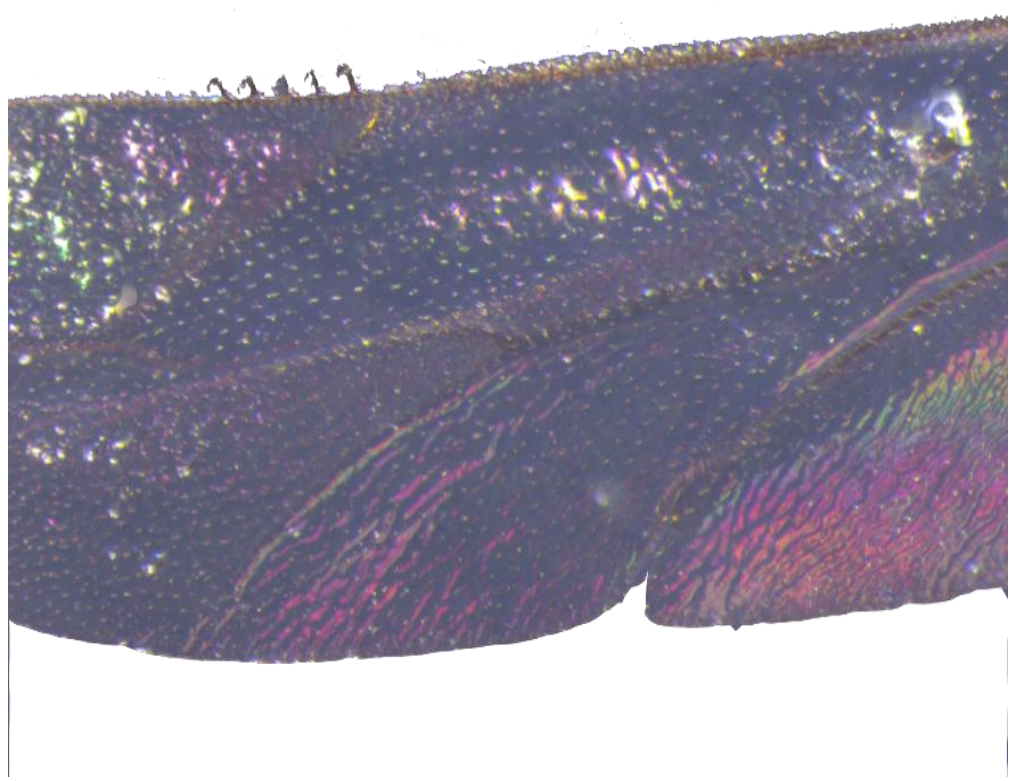

Fig. 2 T. iridipennis hind wing with hamulai under Leica M 165C stereo microscope 


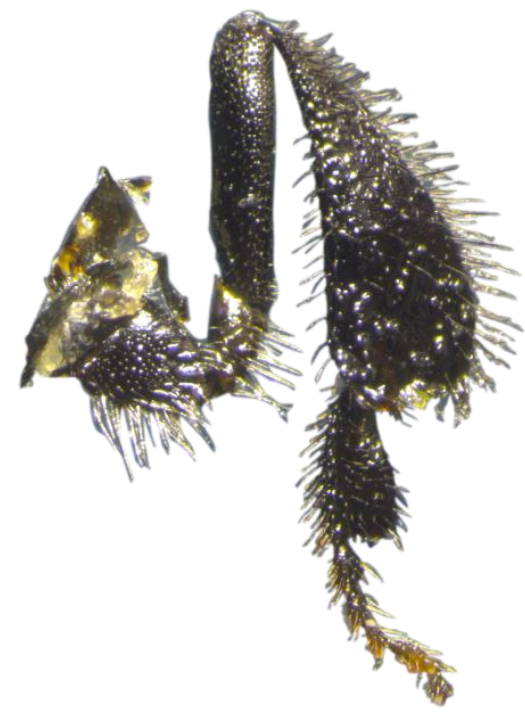

Fig.3 T. iridipennis hind leg under Leica M 165C stereo microscope

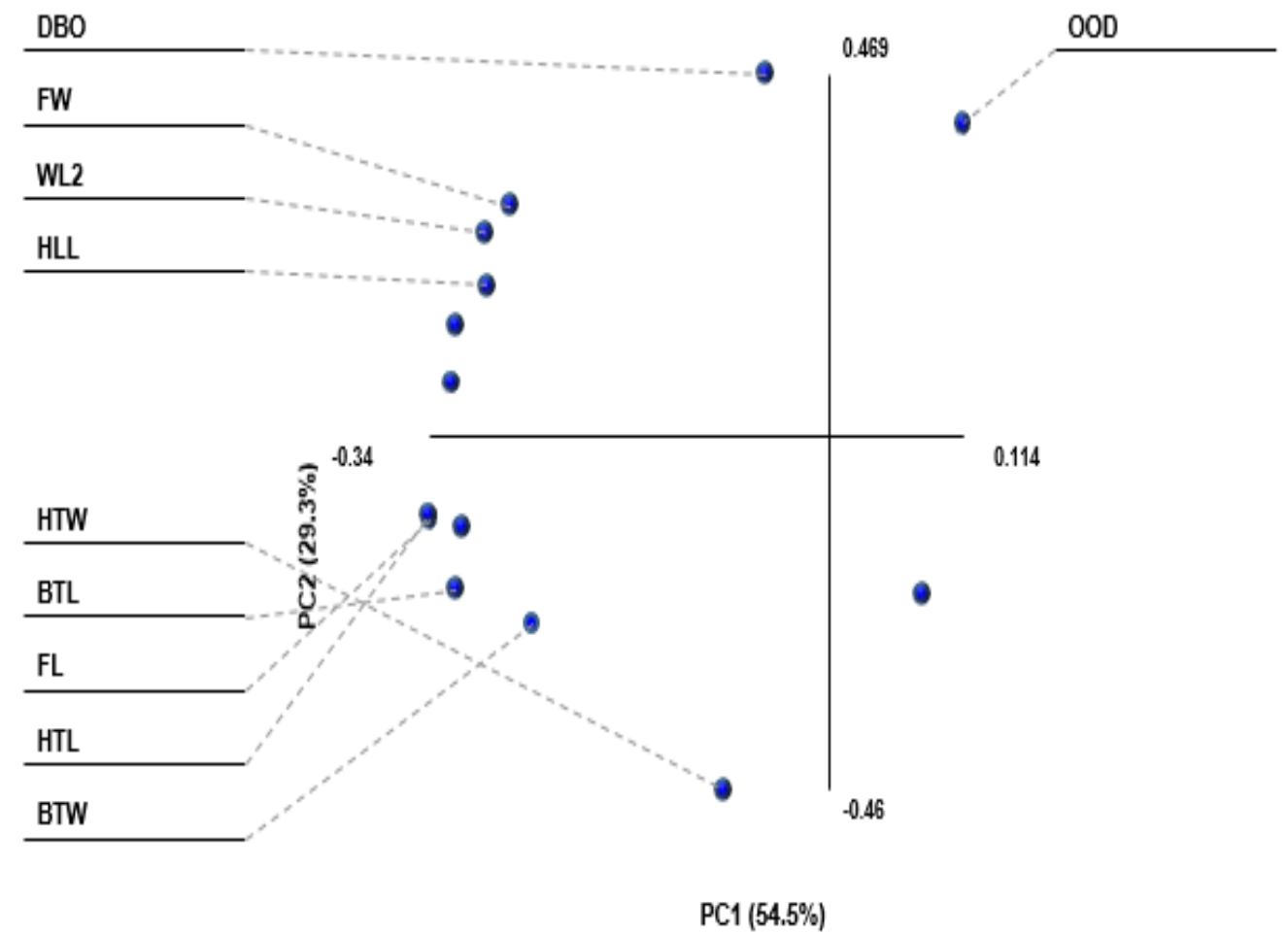

Fig.4 Discriminative characters recorded through principle component analysis 


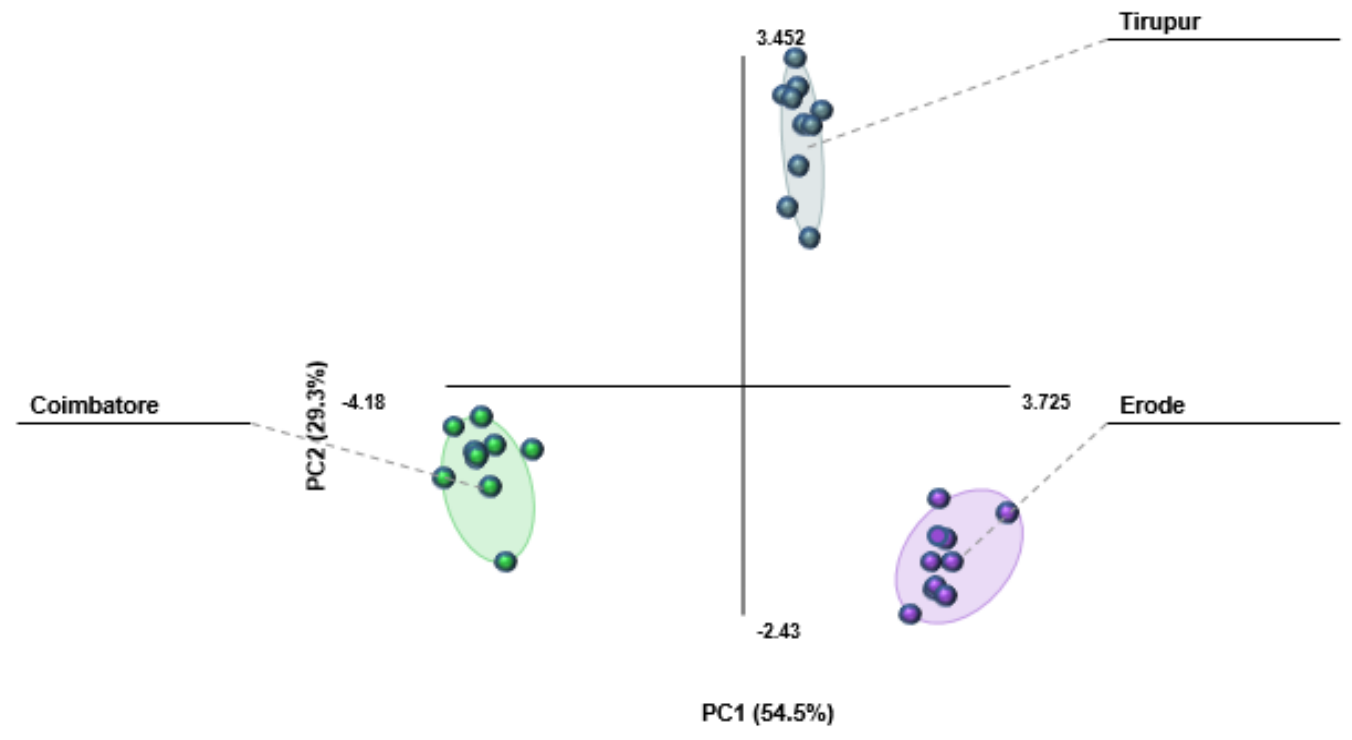

Fig.5 Samples forming three clusters through PCA analysis

\section{Thoracic region}

Hind leg length (HLL), hind tibial length(HTL), hind tibial width (HTW), hind basitarsus length (HBL), fore wing length (FL), fore wing width (FW), bifurication between veins $\mathrm{M}$ and $\mathrm{Cu}$ (WL2) and number of hamuli in hind wing $(\mathrm{NH})$ were the characters studied in the thoracic region. Among the parameters, the average HLL was highest in samples of Coimbatore district (3.46mm) compared to $3.40 \mathrm{~mm}$ in Tiruppur district and $3.26 \mathrm{~mm}$ (Table 3) in Erode district. Similarly HTL was highest in Coimbatore $(1.62 \mathrm{~mm})$ and lowest in Erode district. However, there was no difference observed in number of hamuli (5) irrespective of the district from which bees are collected. Our study is in concurrence with Danaraddi, 2007; reported that the number of hamuli recorded was 5 in Tetragonula collected from different places in Karnataka. Danaraddi, 2007also stated that the length of tibia in $T$. iridipennis varied from 1.32 to $1.39 \mathrm{~mm}$ whereas the width varied from 0.47 to 0.50 mm. Rasmussen, 2013stated thatthe length and width of tibia were 1.43 and $0.57 \mathrm{~mm}$ in
Lepidotrigona arcifera, 0.86 and $0.31 \mathrm{~mm}$ in Lisotrigonacacciae, 1.55 and $0.54 \mathrm{~mm}$ in Tetragonula iridipennis, 1.47 and $0.54 \mathrm{~mm}$ in T. praeterita, 1.43 and $0.52 \mathrm{~mm}$ in $T$. ruficornisand 1.51 and $0.54 \mathrm{~mm}$ in $T$. bengalensis. Swaminathan (2000) recorded the hind wing length of $2.24 \mathrm{~mm}$ in T.iridipennis collected from Tamilnadu. Rahman and Das (2013) reported that the length and width of head of $T$. iridipennis ranged from $0.96-1.12 \mathrm{~mm}$ and $1.16-1.26$ respectively. The sample means yielded 3 factors with high eigenvalues. Analysis of variance of morphometric characters showed that all the 14 morphometric variables studied, displayed statistically significant differences among groups $(\mathrm{P}>0.05)$

\section{Principal component anaysis}

Measurments were made for 30 Stingless bees collected from Coimbatore, Erode and Tirupur districts (10 bees from each location). Each individual bee have been measured in respect of 14 potentially important characters (Table 2). Finally, the data matrix consisted of 420 measurements was constructed 
(comprised of 14 characters of 30 individuals belonging to three districts). The results of PCA showed that the cumulative variance of the three principal components reached 54.\% (PC 1), 29.3\% (PC 2) and 6.2\% (PC 3). The most discriminative characters recorded in the principle component analysis are FL, HTL, BTL, HW, FW, AL and WL2 (Fig. 4). These characters supported in forming three distinct clusters (coimbator, Erode and Tirupur) Figure 5.

\section{References}

Akahira,Y., Sakagami, S.F., 1959. A biometrical study on the Japanese honey bee observations uponsome populations of Kyushu. Journal of Hokkaido, Gakugei University 14, I75-184.

Alpatov, W. W., 1929. Growth and Variation of the Larva of Drosophila melanogaster. Journal of Experimental Zoology 52, 407.

Bassindale, R., Harrison Matthews, L., 2009. The biology of the Stingless Bee Trigona (Hypotrigona) gribodoimagretti (Meliponidae). Journal of Zoology 125(1), 49-62.

Batista, M. A., Ramalho, M., Soares, A. E. E., 2003. Nesting sites and abundance of Meliponini (Hymenoptera: Apidae) in heterogeneous habitats of the Atlantic Rain Forest, Bahia, Brazil. Lundiana, 4(1), 19-23.

Bingham, C. T., 1897. The fauna of British India including Ceylon and Burma. Hymenoptera. Vol.I, Wasps and Bees. Taylor and Francis, London.579 pp.

Danaraddi, C. S., 2007. Studies on stingless bee, Trigonairidipennis Smith with special reference to forage behaviour and melissopalynology at Dharwad, Karnataka. M.Sc (Ag.) thesis, University of Agricultural Sciences, Dharwad. 67p.

Devanesan, S., Shailaja, K. K., Raakhee, M., Bennet, R., Premaila, K. S., 2003. Morphometric characters of the queen and worker of stingless bees, Trigonairidipennis Smith. Insect
Environment 9(4), 154-155.

Franck, P., Cameron, E., Good, G., Rasplus, J. Y., Oldroyd, B.P., 2004. Nest architecture and genetic differentiation in a species complex of Australian stingless bees. Molecular Ecology13, 2317-2331.

Gajanan, S. M., 2005. Studies on distribution, nest architecture, foraging behaviour and biometrics of stingless bee, Trigonairidipennis Smith.(Hymenoptera: Apidae). M.Sc (Ag.), Thesis, University of Agricultural Sciences, Bangalore.

Hepburn, H.R., Radloff, S.E., Verma, S., Verma,L.R., 2001. Morphometric population of Apis cerana populations in the southern Himalayan region. Apidologie 32, 435-448.

Jagannadham, G., Goyal, N.P., 1980. Morphological and behavioral characteristics of honey bee workers reared in combs with larger cells, 2nd International Conference Apiculture in Tropical Climates, New Delhi 2, pp.238253.

Kapil, R.P., 1956. Variation in biometrical characters of the lndian honey bee (Apis indica F.), Indian Journal of Entomology $18,440-451$

KishanTej, M., Aruna, R., Geetanjali, M., Srinivasan, M.R., 2017. Beekeeping in India. Omkar (ed.), Industrial Entomology Springer Nature, Singapore. 39.

Kshirsagar, K.K., 1976. Studies on Indian Apidae with special reference to Indian hive bee, Apisindica. Indian Bee Journal $35,21-26$.

Kshirsagar, K.K., 2013. Comparative biometric studies on Indian honey bees. III. Preliminaryobservations on biometry of Apiscerana F. Queen, Indian Bee Journal 35,21-26.

Kshirsagar, K.K., Ranade, D.R., 1981. Morphometric characterization of Indian hive bee Apis ceranaindica F. (Apidae, Hymenoptera), worker. Journal of the University of Poona, Science and technology Section. 54, 101-120.

Maa, T., 1953. An inquiry into the systematics 
of the Tribus Apidini or honey bees (Hymenoptera) Treubia 21, 525-640.

Michener, C.D., 2000. The bees of the world. Johns Hopkins University Press, Baltimore

Narayanan, E.S., Sharma, P.L., Phadke, K.G., 1960a. Studies on biometry of the Indian bees. I. tongue length and number of hooks on the hind wing of Apisindica. Indian Bee Journal 22, 58-63.

Narayanan, E.S., Sharma, P.L., Phadke,K.G., 1960 b. Studies on the biometry of the Indian bee. Indian Bee Journal 22, 81-88.

Nayak Pavithra, P., Reddy Shankar, M., Jayaprakash., 2013. Nesting pattern preferences of stingless bee, Trigonairidipennis Smith (Hymenoptera: Apidae) in Jnanabharathi Campus, Karnataka, India. International research journal of biological science. 2(2), 44-50.

Raakhee, M., Devanesan, S., 2000. Studies on the behavior of the stingless bee, Trigonairidipennis Smith (Apidae: Meliponinae). Indian Bee Journal 62, 5962.

Rahman, A., Das, P. K., 2013. Morphometry of stingless bees. In: Monograph on Morphometry and phylogeography of honey bees and stingless bees in India. pp 189- 200.

Rahman, A., Das, P. K., 2013. Morphometry of stingless bees. In: Monograph on Morphometry and phylogeography of honey bees and stinglessbees in India. pp 189-200

Rahman, K.A., Singh, S., 1940. Beekeeping in India. Indian Farming 1, 10-17.
Rasmussen, C., 2013. Stingless bees (Hymenoptera: Apidae: Meliponini) of the Indian sub-continent: diversity, taxonomy and current status of knowledge. Zootaxa 3647(3), 401-402.

Roopa, A. N., 2002. Bioecology of stingless bee Trigonairidipennis Smith.(Hymenoptera: Apidae). M.Sc (Agri). Thesis, University of Agricultural Sciences, Bangalore.

Roubik, D. W., 2006. Stingless bee nesting biology. Apidologie37, 124-143.

Ruttner, F., 1988. Biogeography and Taxonomy of Honey bees. xii 284pp. Berlin: Springer.

Sakagami, S.F., 1978. Stingless bees (excl. Tetragonula) from the continental Asia and Sri Lanka (Hymenoptera: Apidae).J. Faculty of Science, Hokkaido University Series VI. Zoology,2lt 165247.

Sakai, T., 1958. Morphological studies on the drone honey bees, Jap. Bee Journal(11) 40-46 (in Japanese).

Swaminathan, T., 2000. Studies on stingless bees. M. Sc. (Ag) Thesis, Tamil Nadu Agricultural University, Coimbatore, 132 p.

Swaminathan, T., 2000. Studies on stingless bees. M.Sc. Thesis, Tamil Nadu Agricultural University Coimbatore (India).

Venkatasubbya, G., 1938. Variation in tongue length of the honey bees. Journal of Mysore Agric Experimental Station 17, 65-72.

Wille, A., 1983. Biology of the stingless bees. Annual Review of Annual Review of Entomology 28:41-64.

\section{How to cite this article:}

Kishan Tej, M., M.R. Srinivasan, K. Vijayakumar, N. Natarajan and Mohan Kumar, S. 2017. Morphometry Analysis of Stingless Bee Tetragonula iridipennis Smith (1854). Int.J.Curr.Microbiol.App.Sci. 6(10): 2963-2970. doi: https://doi.org/10.20546/ijcmas.2017.610.350 